\title{
Bosnia and Herzegovina
}

National Cancer Institute

\section{Source}

National Cancer Institute. Bosnia and Herzegovina. NCI Thesaurus. Code C16361.

A country in southeastern Europe, bordering the Adriatic Sea, between Croatia and Serbia. 